\title{
Introduction: Shrinking Civic Space in Indonesia
}

\begin{abstract}
After careful consideration, the editors selected four articles and two comment pieces to make up the June Volume 5 Issue 1, 2021. The four articles discuss human rights issues in Indonesia through various perspectives, including: philosophical, historical, and legal. First, the editor chose an article discussing the Pancasila philosophy as an analytical perspective to explore the dynamics of human rights in Indonesia. Following this, comes an article analysing the 'dark history' of serious human rights abuses in Indonesia, namely the 1965 massacre. The editor believes that this 'dark history' is important for readers to acknowledge when exploring Indonesia's contemporary human rights landscape. The final article discusses the government's challenge of establishing inclusive villages for persons with disabilities, with particular focus on district- and city-level implementation. The final article was chosen since JSEAHR has never published an article that explores the role of the military in eradicating terrorism, which is believed to have contributed to human rights violations.
\end{abstract}

The editor has also included two comment pieces from book reviews that discuss religious freedom and the dynamics of human rights in Indonesia. The first is a review of the book "Religious Minorities, Islam and the Law: International Human Rights and Humanitarian Law,” by Abubakar Eby Hara. The second reviews the book "Kebebasan Beragama atau Berkeyakinan di Indonesia: Perspektif Filosofis, Hukum dan Politik." Unlike many other journals, JSEAHR deliberately publishes longer versions of book reviews. The editor hopes that this will provide readers with the resources to develop a greater insight into the issues covered in this book as well as developing a more comprehensive understanding of discourses surrounding human rights and their violation.

These four articles and two comment pieces do not claim to provide a comprehensive account of the human rights situation in Indonesia or the Southeast Asia Region but highlight some key issues within this field. Over the past decade, the human rights situation in both Indonesia specifically, and in Southeast Asia more generally, has been very dynamic. Duterte's anti-drug policy, the 'war on narcotics' in the Philippines has had deeply concerning effects on the reality of human rights in the country. The military coup in Myanmar also seemed to complement concerns about the stagnation of the ASEAN regional mechanism in advancing human rights in the region. The collapse of the ASEAN regional mechanism will certainly lead to a regression of human rights in regional countries due to increasingly serious policy disparities from countries in Southeast Asia regarding human rights. 
For a long time, the totalitarian regime in Brunei and the stuffy democracy in Malaysia and Singapore have stagnated the space for human rights in Southeast Asia. Unfortunately, Indonesia, as the largest country in the region, is also showing signs of declining human rights. Over the past decade, the Indonesian government has set a set of policies that have shrunk democratic space. The riots and conflicts in Papua, the lack of transparency relating to the enactment of an omnibus law that focuses on economic development, and the repression of freedom of expression show signs of democratic regression in Indonesia. Indonesia's longer-standing commitment to the promotion of human rights, including gender equality and minority inclusion, are far from being fully realised. This reality demonstrates that since the fall of Suharto in 1998, Indonesia has continued to struggle to improve civil rights.

Freedom House reported that democracy index in Indonesia has not changed in 2020 from the score of 62 to 61 out of a total score of 100. The 2021 index shows that Indonesia has fallen slightly to 59 , which put human rights and democracy process in Indonesia are in alert.' This means that democracy in Indonesia is still considered 'partly free'. Civil and political rights contribute significantly to this index but continue to score poorly. ${ }^{2}$ In fact, the score for civil liberties in 2020 is almost the same as the score during the New Order era, suggesting that civil and political rights have stagnated, or even regressed. For example, in the last decade, the government has repressed freedom of expression and freedom of assembly particularly around sensitive topics. The government also uses an exclusive mechanism to enact legislation that is only concerned with protecting their interests, such as the omnibus law that forced university students and Civil Society Organisations (CSO) to stage mass demonstration.

This also means that the fall of the New Order has not facilitated substantial national reforms toward the establishment of a sustainable liberal democracy. Indonesia has experienced significant shrinking of democratic space, particularly in areas relating to civil liberties - namely, freedom of expression, freedom of assembly, and freedom of association. ${ }^{3}$ Law No. 19/2016 on Electronic Information and Transaction (UU ITE) has also reduced freedom of expression through the criminalization of activists and opposition figures. This regulation endangers the democratic climate because criticism of, and advocacy against, the government, that

1 "Indonesia: Freedom in the World 2021 Country Report", online: Freedom House <https://freedomhouse.org/country/indonesia/freedom-world/2021>.

2 "Indonesia: Freedom in the World 2020 Country Report", online: Freedom House <https://freedomhouse.org/country/indonesia/freedom-world/2020>.

3 Hurriyah Hurriyah, "Upaya pemerintah membatasi kebebasan sipil dalam tarik ulur perpanjangan izin FPI”, (17 December 2019), online: The Conversation <http://theconversation.com/upayapemerintah-membatasi-kebebasan-sipil-dalam-tarik-ulur-perpanjangan-izin-fpi-128462>. 
should be part of society's checks and balances system, can easily be suppressed and criminalized.

In its 2020 annual report digital rights and freedom watchdog SAFEnet highlighted the significant increase of criminalisation of internet users during the Covid-19 pandemic, reporting 84 cases in 2020 compared to 24 the year prior. ${ }^{4}$ Two Laws are commonly used in these cases. The first is the ITE Law, especially Article 28, paragraph 2 concerning Hate Speech (used in 27 cases,) Article 27, paragraph 3 concerning defamation (used in 22 cases,) and Article 28, paragraph 1 concerning fake news. The second regulation is Law No. 1/1946 regarding Disturbances or Chaos, Articles 14-15 (used in 21 cases) as well as several articles relating to defamation in the Indonesian Criminal Code. ${ }^{5}$ Not only does this criminalization threaten the ongoing democratic transition, but the prosecution and conviction of journalists and activists further compromises freedom of expression and press in Indonesia.

Indonesia's democracy is in decline. Without significant changes to and improvement of the political landscape, the prospect of Indonesia slipping into a new form of authoritarian rule becomes a legitimate and serious concern. The articles and commentaries included in this issue should be enough to convince everyone that the promotion of human rights in an authoritarian Indonesia will be increasingly challenging. The editor hopes that the selected articles will increase readers' knowledge about past and current human rights realities in Indonesia.

The editorial office is thankful to the language editor, Maya White, and copy editor Cindy Claudia Putri who have worked hard to ensure the articles in this volume are of the highest quality, correcting grammatical errors and ensuring the accuracy of reference citations.

Jember, 25 June 2021

Al Khanif, Editor

4 Represi Digital di tengah Pandemi, Annual Report, by A Ryan Sanjaya et al, Laporan Situasi HakHak Digital Indonesia Annual Report (Jakarta: SAFEnet, 2021) at 12.

5 Ibid at 12-13. 